\title{
Design, Synthesis, and Antiviral Activity of Adenosine 5'-Phosphonate Analogues as Chain Terminators against Hepatitis C Virus
}

\author{
Yung-hyo Koh, ${ }^{\dagger}$ Jae Hoon Shim, ${ }^{\dagger}$ Jim Zhen Wu, Weidong Zhong, Zhi Hong, and Jean-Luc Girardet* \\ Drug Discovery, R\&D, Valeant Pharmaceuticals International, 3300 Hyland Avenue, Costa Mesa, California 92626
}

Received November 30, 2004

A series of adenosine 5'-phosphonate analogues were designed to mimic naturally occurring adenosine monophosphate. These compounds $(\mathbf{1}-\mathbf{5})$ were synthesized and evaluated in a cellular hepatitis $\mathrm{C}$ virus (HCV) replication assay. To improve cellular permeability and enhance the anti-HCV activity of these phosphonates, a bis ( $S$-acyl-2-thioethyl) prodrug for compound $\mathbf{5}$ was prepared, and its cellular activity was determined. To elucidate the mechanism of action of these novel adenosine phosphonates, their diphosphate derivatives $(\mathbf{1 a}-\mathbf{5 a})$ were synthesized. Further nucleotide incorporation assays by HCV NS5B RNA-dependent RNA polymerase revealed that $\mathbf{2 a}$ and $\mathbf{3 a}$ can serve as chain terminators, whereas compounds $1 \mathbf{a}, \mathbf{4 a}$, and $\mathbf{5 a}$ are competitive inhibitors with ATP. Additional steady-state kinetic analysis determined the incorporation efficiency of $\mathbf{2 a}$ and $\mathbf{3 a}$ as well as the inhibition constants for 1a, $\mathbf{4 a}$, and $\mathbf{5 a}$. The structure-activity relationships among these compounds were analyzed, and the implication for nucleoside phosphonate drug design was discussed.

\section{Introduction}

$\mathrm{HCV}$ is the major causative agent for non-A, non-B virally induced hepatitis. ${ }^{1}$ As an insidious and deadly disease, $\mathrm{HCV}$ infection is responsible for an emerging pandemic of chronic liver diseases. There are 170 million infected individuals worldwide and approximately 4 million HCV carriers in the United States alone. Unresolved acute $\mathrm{HCV}$ infections progress to a chronic disease that persists for decades. As much as $20 \%$ of the infected individuals eventually develop liver cirrhosis with $1-5 \%$ subsequently leading to hepatocellular carcinoma. ${ }^{2}$ This type of cancer accounts for nearly 10000 deaths annually in the US. The current standard of care treatment is a combination of subcutaneous pegylated interferon- $\alpha$ with oral nucleoside drug ribavirin. ${ }^{3}$ The sustained viral response, defined as undetectable viral load for 6 months following cessation of therapy, is around 54-56\% for this combination therapy. Therefore, there is still room for the treatment to be improved in term of efficacy as well as safety. One approach is to develop direct antiviral chemotherapy against a viral target. HCV NS5B is the viral RNAdependent RNA polymerase ( $\mathrm{RdRp}$ ) that is responsible for viral genome replication. It constitutes a valid target for drug discovery. ${ }^{4}$

Nucleoside chain terminators comprise a major class of drugs that targets a viral polymerase. The chemically unique chain terminators that have been proved clinically useful include acyclovir (ACV) and gancyclovir (GCV) for herpes virus infection, zidovudine (AZT), didanosine (ddI), zalcitabine (ddC), stavudine (d4T), abacavir (ABC), and tenofovir (TDF) for HIV/AIDS, lamivudine (3TC) and adefovir (ADV) for HBV, and cidofovir for cytomegalovirus retinitis in AIDS patients. Although most of them are nucleoside analogues, teno-

* To whom correspondence should be addressed. Telephone: 714545-0100, ext. 4204. Fax: 714-641-7222. E-mail: jlgirardet@valeant.com. $\dagger$ These investigators contributed equally to this work. fovir, adefovir, and cidofovir are acyclic nucleoside phosphonates. ${ }^{5}$ Generally, nucleosides are prodrugs, and their biological activity is exerted by their 5 '-triphosphate derivative. Intracellular phosphorylation is required to convert a nucleoside drug to its active $5^{\prime}$ triphosphate in order to be incorporated into a viral DNA. The sequential phosphorylation is normally executed by three viral or cellular kinases, including nucleoside kinase, nucleoside monophosphate kinase, and nucleoside diphosphate kinase. ${ }^{6}$ Once incorporated into an elongating viral DNA chain, the nucleotide inhibitor functions as a chain terminator to abort viral DNA synthesis.

A nucleoside 5'-phosphonate is essentially a nucleoside monophosphate analogue. However, a phosphonate has the advantage over its phosphate counterpart of being metabolically stable, as its phosphorus-carbon bond is not susceptible to phosphatase hydrolysis. More importantly, the presence of a 5'-phosphonate allows the first phosphorylation step required for nucleoside activation to be skipped, therefore bypassing this inefficient and often rate-limiting step in the conversion to $5^{\prime}$ triphosphate. Like a nucleoside monophosphate, a nucleoside phosphonate can be further phosphorylated by cellular nucleotide kinases. The concept of nucleoside phosphonate has been applied to design chain terminators for anti-HIV chemotherapy and proved to be valid. 9-(2-Phosphonylmethoxypropyl)adenine (PMPA) and 9-(2-phosphonylmethoxyethyl)adenine (PMEA) are two effective and potent nucleoside phosphonate chain terminators for HIV reverse transcriptase (RT). ${ }^{7-9}$ Mechanism of action studies show that incorporation of PMPA diphosphate (PMPApp) by HIV-RT is almost as efficient as that of dATP or ddATP. ${ }^{10}$ Despite this success, the concept of nucleoside phosphonate has not been fully explored for RNA viruses. ${ }^{5}$ In this study, we designed and synthesized a series of 5'-deoxyadenosine 

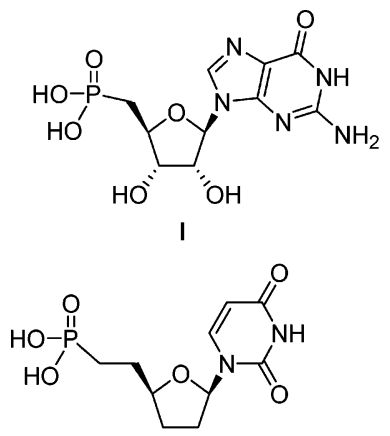

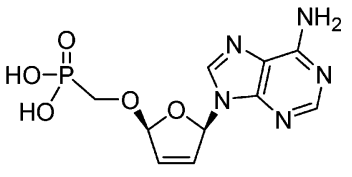

II

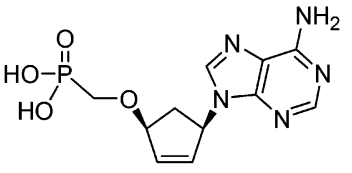

IV

Figure 1. Examples of nucleoside phosphonates designed for DNA virus and retrovirus.

phosphonates and evaluated their antiviral activity against $\mathrm{HCV}$, an RNA virus.

In the literature, several 5'-phosphate isosteres have been adopted to prepare nucleoside phosphonates. As shown in Figure 1, compounds $\mathbf{I}^{11}$ and $\mathbf{I I I} \mathbf{I}^{12,13}$ are simple 5 -deoxy nucleoside phosphonates, in which the 5'oxygen of a nucleoside phosphate is either removed or replaced by a methylene group. Alternatively, in compounds $\mathbf{I I}^{14}$ and $\mathbf{I V},{ }^{15}$ the $5^{\prime}$-oxygen and -carbon are simply swapped to yield a phosphonate. All of the resultant phosphonates mimic the overall shape and geometry of a nucleoside monophosphate. We applied the same strategy to an adenosine ribonucleotide scaffold and designed a series of 5'-deoxyadenosine phosphonate analogues (Figure 2, compounds 1-4). It has been reported that addition of a 2'-methyl group onto ATP yields a potent chain terminator for HCV NS5B RdRp. ${ }^{16}$ Hence, an adenosine phosphonate with the 2 methyl addition was also conceived (Figure 2, compound 5). Since the ionic character of a phosphonic acid would present an obstacle for cellular permeability, an $S$-acyl2-thioethyl (SATE) prodrug (5b) for compound $\mathbf{5}$ was also prepared. Esterification of a phosphonic acid with two SATE groups has been proven to be a feasible strategy to deliver a phosphate or phosphonate drug into cells. ${ }^{17}$ We report here the synthesis of adenosine phosphonate analogues $\mathbf{1}-\mathbf{5}$, their corresponding diphosphate derivatives $\mathbf{1 a}-\mathbf{5 a}$, and a bis-SATE prodrug $\mathbf{5 b}$. The cellular activity of $\mathbf{1 - 5}$ and $\mathbf{5 b}$ were evaluated in a HCV replication assay. Moreover, kinetic analysis was performed for phosphono diphosphate derivatives $\mathbf{1 a}-$ 5a as an ATP analogue for NS5B RdRp. The implication for future nucleoside phosphonate chain terminator design is discussed.

Scheme $1^{a}$

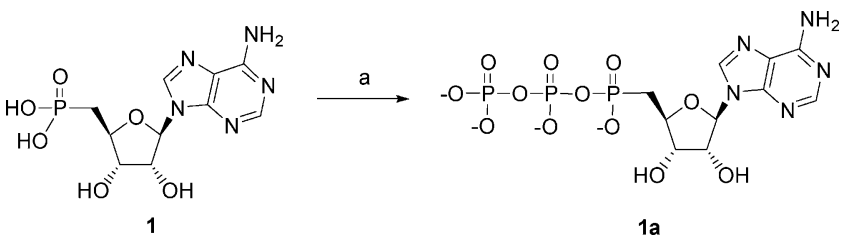

${ }^{a}$ Reagents and conditions: (a) $\mathrm{Bu}_{3} \mathrm{~N}, 1,1^{\prime}$-carbonyldiimidazole, DMF; $\left(\mathrm{HNBu}_{3}\right)_{2} \mathrm{H}_{2} \mathrm{P}_{2} \mathrm{O}_{7}$; TEAB buffer.

\section{Results}

Synthesis of Adenosine Phosphonate Analogues and Their Diphosphate Derivatives. Adenosine phosphonate 1 was synthesized following the literature procedure of Raju et al. ${ }^{11}$ To prepare its diphosphate derivative 1a, 1 was reacted with 1,1'-carbonyldiimidazole (CDI) in DMF followed by bis(tri- $n$-butylammonium) pyrophosphate. The diphosphate obtained from the reaction contained a $2^{\prime}, 3^{\prime}$-cyclic carbonate moiety because of the coupling between 2'- and 3'-hydroxyl groups of 1 with CDI. The cyclic carbonate was hydrolyzed by treatment with triethylammonium bicarbonate (TEAB) buffer to give the phosphono diphosphate 1a (Scheme 1).

For the synthesis of nucleoside phosphonate 2, the previously reported synthetic routes ${ }^{18,19}$ were adopted with some modifications (Scheme 2). Treatment of $N^{6}, 2^{\prime}, 3^{\prime}$-tribenzoyladenosine (6) with dicyclohexylcarbodiimide $^{11}$ and DMSO in the presence of pyridinium trifluoroacetate produced a $5^{\prime}$-aldehyde, which was later reacted with diphenyl triphenylphosphoranylidenemethylphosphonate ${ }^{20}$ to yield the corresponding $5^{\prime}, 6^{\prime}$-vinyl phosphonate. Catalytic hydrogenation of the vinyl phosphonate in the presence of palladium on carbon gave a saturated phosphonate ester $\mathbf{7}$. Transesterification of $\mathbf{7}$ with sodium benzoxide resulted in $\mathbf{8}$ in a good yield. Deprotection of benzoyl groups of $\mathbf{8}$ followed by palladium-catalyzed hydrogenolysis of benzyl ester provided the nucleoside phosphonate 2 . Its diphosphate derivative $\mathbf{2 a}$ was prepared using the same reaction conditions as described in Scheme 1.

Nucleoside phosphonate 3 was synthesized by following a literature procedure ${ }^{14}$ in nine steps starting from adenosine. The diphosphate derivative $\mathbf{3 a}$ was prepared by activation of $\mathbf{3}$ with CDI followed by reaction with pyrophosphate as described in Scheme 1 (Scheme 3).

Merlo et al. had previously reported the synthesis of the carbocyclic nucleoside phosphonate 4 by employing enzyme-catalyzed resolution method..$^{21}$ Our chemical
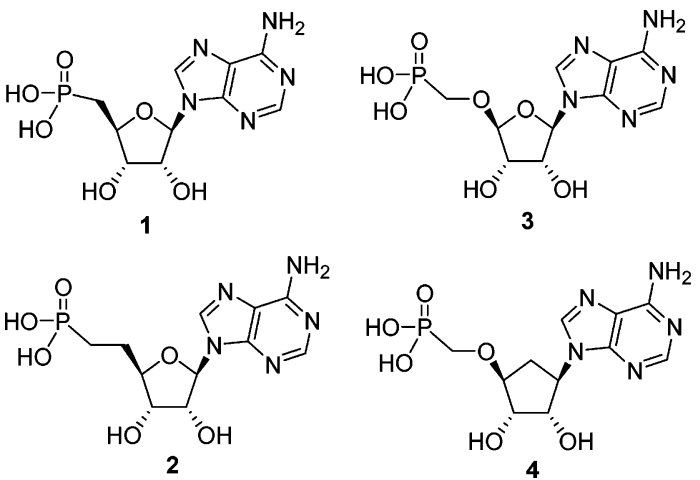

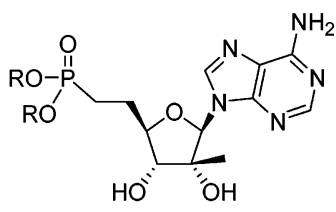

$5 \quad \mathbf{R}=\mathbf{H}$

5b $\quad R=$ tBuSATE

Figure 2. Adenosine phosphonate analogues designed for HCV NS5B RdRp. 
Scheme $2^{a}$
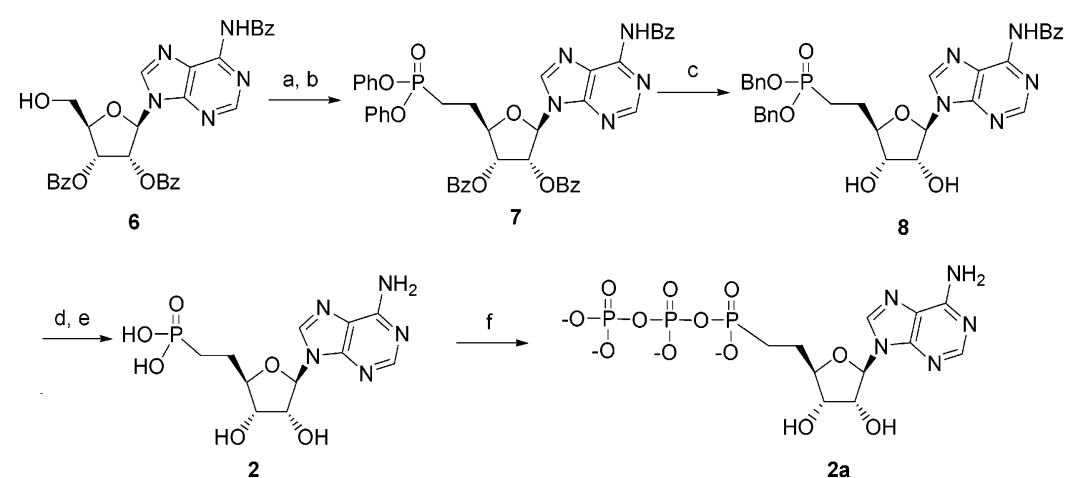

${ }^{a}$ Reagents and conditions: (a) DCC, DMSO, TFA, pyridine; $(\mathrm{PhO})_{2} \mathrm{P}(=\mathrm{O}) \mathrm{CHPPh}_{3}$; (b) $\mathrm{H}_{2}, \mathrm{Pd}-\mathrm{C}, \mathrm{CH}_{3} \mathrm{OH} ;(\mathrm{c}) \mathrm{NaH}, \mathrm{BnOH}, \mathrm{DMSO}$; (d) $\mathrm{NH}_{3}, \mathrm{CH}_{3} \mathrm{OH}$; (e) $\mathrm{H}_{2}, \mathrm{Pd}-\mathrm{C}, \mathrm{CH}_{3} \mathrm{OH}$; (f) $\mathrm{Bu}_{3} \mathrm{~N}, 1,1^{\prime}$-carbonyldiimidazole, DMF; $\left(\mathrm{HNBu}_{3}\right)_{2} \mathrm{H}_{2} \mathrm{P}_{2} \mathrm{O}_{7}$; TEAB buffer.

\section{Scheme $3^{a}$}
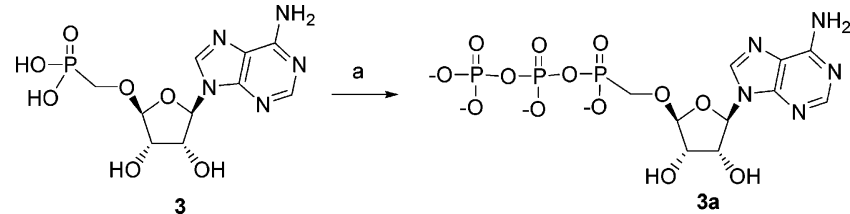

${ }^{a}$ Reagents and conditions: (a) $\mathrm{Bu}_{3} \mathrm{~N}, 1,1^{\prime}$-carbonyldiimidazole, $\mathrm{DMF} ;\left(\mathrm{HNBu}_{3}\right)_{2} \mathrm{H}_{2} \mathrm{P}_{2} \mathrm{O}_{7}$; TEAB buffer.

synthesis of 4 began with $(1 R, 4 S)$-9-(4-hydroxycyclopent-2-en-1-yl)adenine $\mathbf{9}$, which was prepared by $\operatorname{Pd}(0)$-catalyzed coupling of 6 -chloropurine with chiral cyclopentene-1,3-diol 1-acetate (Scheme 4). ${ }^{22,23}$ Initial attempts to alkylate the oxygen at $\mathrm{C} 4$ of $\mathbf{9}$ with diethyl $p$-tolylsulfonyloxymethyl phosphonate $\mathbf{1 1}$ in the presence of a catalytic base resulted in a mixture of several inseparable products. Therefore, we decided to first convert $\mathbf{9}$ to its $N, N$-dimethylformamidine derivative $\mathbf{1 0}$. Further treatment of the protected nucleoside $\mathbf{1 0}$ with phosphonate ester 11 led to clean O-alkylation. Deprotection of the amidine group with methanolic ammonia, followed by bis-hydroxylation with osmium tetraoxide, gave phosphonate ester 12. Hydrolysis of $\mathbf{1 2}$ by treatment with bromotrimethylsilane afforded the carbocylic phosphonate 4 in good yield. A diphosphate derivative 4a was prepared from 4 using the similar reaction conditions as described in Scheme 1.

Synthesis of 2'-C-methyl phosphonate 5 was accomplished by employing a similar synthetic approach developed for the synthesis of phosphonate 2 (Scheme 5). Starting from 2 '-C-methyl adenosine (13), ${ }^{24}$ com- pound 14 was obtained via a silylation, benzoylation, and desilylation sequence. The same chemistry described in Scheme $\mathbf{2}$ was applied to $\mathbf{1 4}$ to make phosphonate $\mathbf{5}$ and its diphosphate derivative $\mathbf{5 a}$.

The bis-SATE prodrug of $\mathbf{5}, \mathbf{5} \mathbf{b}$, was synthesized following a published procedure as illustrated in Scheme 6. ${ }^{17}$ Briefly, phosphonate 5 was reacted with thioester $\mathbf{1 7}$ in the presence of 1-mestylene-2-sulfonyl-3-nitro1,2,4-triazole (MSNT). However, the reaction yielded a $3^{\prime}, 5^{\prime}$-cyclic phosphodiester 18 instead of $\mathbf{5 b}$. To avoid the unwanted cyclization, the 3 '-hydroxyl group of $\mathbf{1 6}$ was protected with a tert-butyldimethylsilyl group. Hydrolysis of the benzoyl amide followed by hydrogenolysis of the benzyl ester provided the protected phosphonate 19, which was then treated with thioester $\mathbf{1 7}$ to afford a protected tert-butyl SATE phosphodiester. Finally, desilylation of the phosphodiester with tetrabutylammonium fluoride in the presence of acetic acid resulted in $\mathbf{5 b}$ with a good yield.

Cellular Activity of Adenosine Phosphonates. A previously reported HCV subgenomic replicon system ${ }^{25}$ was used to evaluate the antiviral activity of adenosine phosphonate analogues $\mathbf{1 - 5}$ and bis-SATE prodrug $\mathbf{5 b}$. In addition, the cytotoxicity of these compounds was assessed in Huh7 cells. The results are summarized in Table 1. Due to its poor solubility in DMSO, no reproducible results were obtained for compound $\mathbf{1}$. For the remaining adenosine phosphonates, compounds 4 and $\mathbf{5}$ are relatively potent with an $\mathrm{EC}_{50}$ of around $30 \mu \mathrm{M}$. By comparison, compounds $\mathbf{2}$ and $\mathbf{3}$ are weaker with an $\mathrm{EC}_{50}$ of 200 and $65 \mu \mathrm{M}$, respectively. None of them

\section{Scheme $4^{a}$}
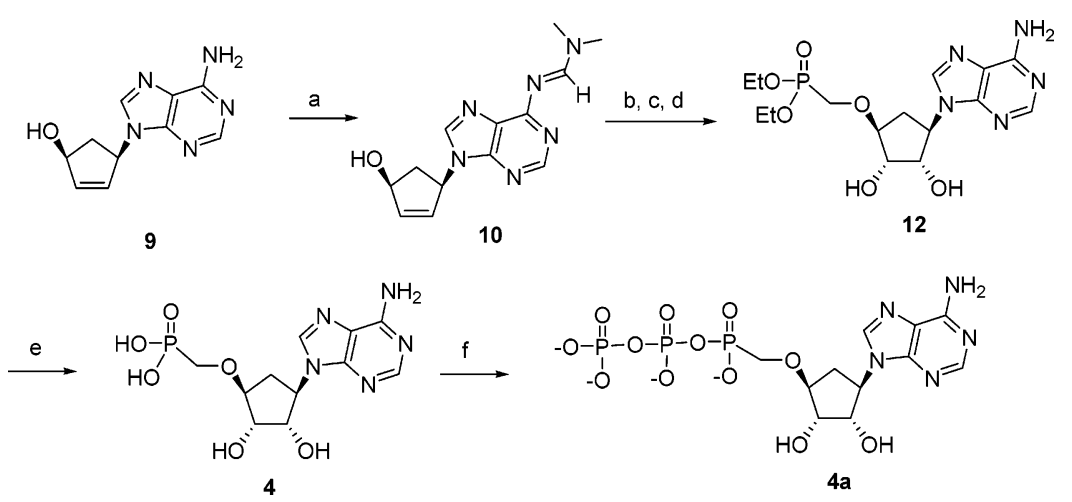

${ }^{a}$ Reagents and conditions: (a) (EtO) $)_{2} \mathrm{CHN}\left(\mathrm{CH}_{3}\right)_{2}$, DMF; (b) NaH, DMF, (EtO) ${ }_{2} \mathrm{POCH}_{2} \mathrm{OTs}$ (11); (c) NH $\mathrm{N}_{3}$, $\mathrm{MeOH}$; (d) OsO morphorine $N$-oxide, acetone- $-t$ - $\mathrm{BuOH}-\mathrm{H}_{2} \mathrm{O}$; (e) TMSBr, DMF; (f) $\mathrm{Bu}_{3} \mathrm{~N}, 1,1^{\prime}$-carbonyldiimidazole, DMF; $\left(\mathrm{HNBu}_{3}\right)_{2} \mathrm{H}_{2} \mathrm{P}_{2} \mathrm{O}_{7}$; TEAB buffer. 


\section{Scheme $5^{a}$}
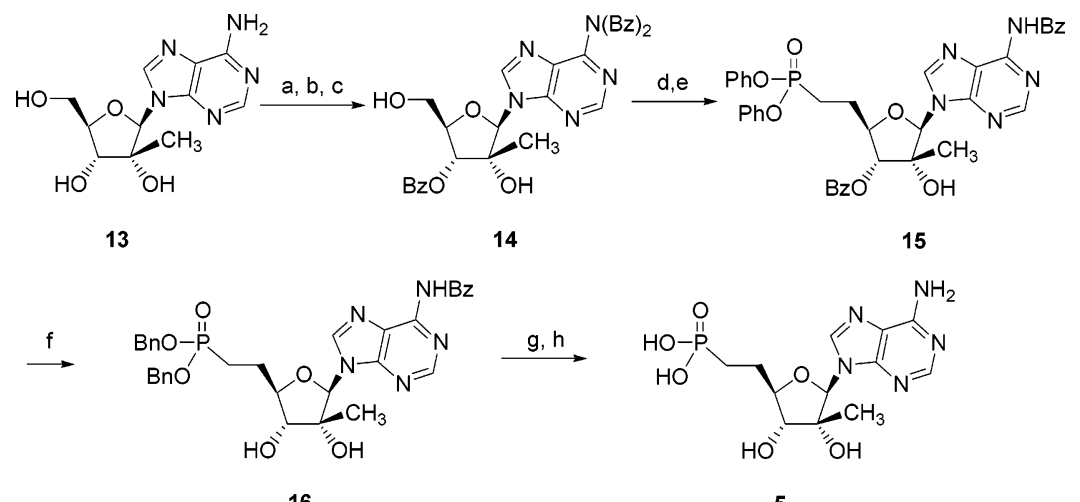

16

5

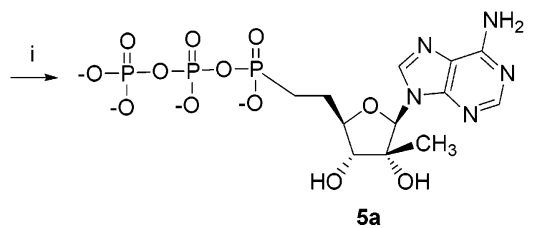

a Reagents and conditions: (a) TBSCl, pyridine; (b) $\mathrm{Bz} 2 \mathrm{O}$, pyridine; (c) TBAF, AcOH, THF; (d) DCC, DMSO, TFA, pyridine; $(\mathrm{PhO})_{2} \mathrm{P}(=\mathrm{O}) \mathrm{CHPPh}_{3}$; (e) $\mathrm{H}_{2}, \mathrm{Pd}-\mathrm{C}, \mathrm{CH}_{3} \mathrm{OH}$; (f) $\mathrm{NaH}$, BnOH, DMSO; (g) $\mathrm{NH}_{3}, \mathrm{CH}_{3} \mathrm{OH}$; (h) $\mathrm{H}_{2}, \mathrm{Pd}^{-\mathrm{C}}, \mathrm{CH}_{3} \mathrm{OH}$; (i) $\mathrm{Bu} 3 \mathrm{~N}, 1,1^{\prime}-$ carbonyldiimidazole, DMF; $\left(\mathrm{HNBu}_{3}\right)_{2} \mathrm{H}_{2} \mathrm{P}_{2} \mathrm{O}_{7}$; TEAB buffer.

\section{Scheme $6^{a}$}
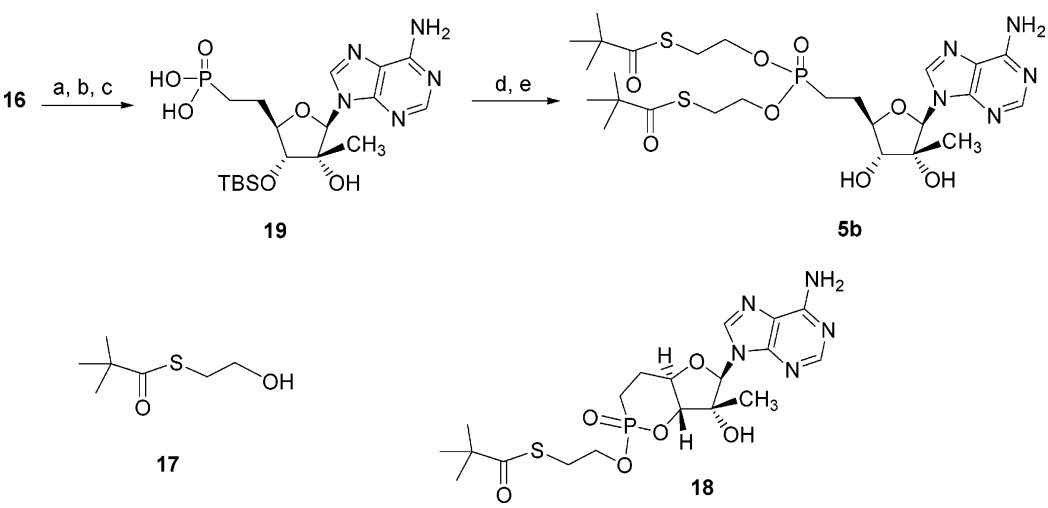

${ }^{a}$ Reagents and conditions: (a) TBSCl, imidazole, DMF; (b) $\mathrm{NH}_{3}, \mathrm{MeOH}$; (c) $\mathrm{H}_{2}, \mathrm{Pd}-\mathrm{C}, \mathrm{MeOH}$; (d) 17, 1-mestylene-2-sulfonyl-3-nitro1,2,4-triazole, pyridine; (e) TBAF, AcOH, THF.

Table 1. Antiviral Activity of Adenosine Phosphonate 1-5 and a Bis-SATE Prodrug 5b in a HCV Subgenomic Replicon Assay and Their Cytotoxicity in Huh7 Cells ${ }^{a}$

\begin{tabular}{cccccc}
\hline compd & $\mathrm{EC}_{50}(\mu \mathrm{M})$ & $\mathrm{CC}_{50}(\mu \mathrm{M})$ & compd & $\mathrm{EC}_{50}(\mu \mathrm{M})$ & $\mathrm{CC}_{50}(\mu \mathrm{M})$ \\
\hline $\mathbf{1}^{b}$ & $\mathrm{ND}$ & $\mathrm{ND}$ & $\mathbf{4}$ & 30 & 300 \\
$\mathbf{2}$ & 200 & $>300$ & $\mathbf{5}$ & 35 & $>300$ \\
$\mathbf{3}$ & 65 & $>300$ & $\mathbf{5 b}$ & 25 & 30 \\
\hline
\end{tabular}

${ }^{a}$ The reported data are an average of at least two sets of results. $b$ The values of $\mathrm{EC}_{50}$ and $\mathrm{CC}_{50}$ were not determined (ND) due to the poor solubility of the compound.

shows any significant cytotoxicity up to $300 \mu \mathrm{M}$. Addition of the 2 -methyl group reduces the $\mathrm{EC}_{50}$ of $\mathbf{2}$ by 6 -fold. This result is consistent with the report in which addition of a $2^{\prime}$-methyl group to ATP makes the resulting triphosphate a potent $\mathrm{HCV}$ inhibitor. ${ }^{16}$ Interestingly, the antiviral activity of compounds $\mathbf{3}$ and $\mathbf{4}$ does not differ much despite their different sugar moieties. This conclusion indicates that the ribose bridge oxygen is not critical for cellular activity. Finally, the bis-SATE prodrug $\mathbf{5 b}$ was found to be slightly more potent than its parental compound $\mathbf{5}$, but its cytotoxicity was somehow enhanced with the $\mathrm{CC}_{50}$ decreased from more than 300 $\mu \mathrm{M}$ for 5 to about $30 \mu \mathrm{M}$ (Table 1).
Incorporation of Nucleoside Phosphono Diphosphates by NS5B RdRp. All diphosphate derivatives $\mathbf{1} \mathbf{a}-\mathbf{5 a}$ of adenosine phosphonates $\mathbf{1}-\mathbf{5}$ resemble the conformation of ATP. They can be potentially recognized by NS5B RdRp, be incorporated into elongating viral RNAs, and act as a chain terminator. Alternatively, even if they cannot be utilized as a substrate, they could serve as a competitive inhibitor against ATP. We investigated the mode of action of these adenosine phosphono diphosphates in a nucleotide incorporation assay as previously described. ${ }^{26}$ In the experiments, an oligo template 5'-AAAAAAAUGC-3' and a dinucleotide primer ${ }^{33} \mathrm{pGpC}$ were used. An adenosine nucleotide substrate would form a Watson-Crick base pair with $\mathrm{U}$ at the third base position in the template. A chain terminator would be incorporated and generate a trinucleotide product. The product is visualized after gel separation followed by Phosphor Imager analysis. As shown in Figure 3, among the five nucleoside phosphono diphosphates tested, only $\mathbf{2 a}$ and $\mathbf{3 a}$ were incorporated by NS5B RdRp and gave a detectable trinucleotide product. Judging from the amount of products formed on the gel, these two compounds are less active than 


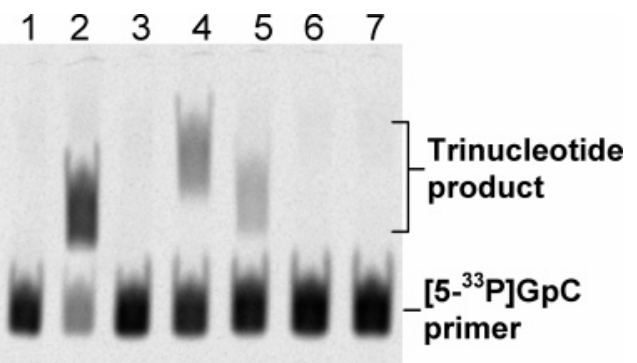

Figure 3. Incorporation of each of adenosine phosphono diphosphates $\mathbf{1 a}-\mathbf{5 a}$ into a dinucleotide $\mathrm{pGpC}$ primer by $\mathrm{HCV}$ NS5B RdRp. An incorporation reaction contained $2.5 \mu \mathrm{M}$ of NS5B RdRp, $20 \mu \mathrm{M}$ of $\left[5-{ }^{33} \mathrm{P}\right] \mathrm{GpC}$ primer, $20 \mu \mathrm{M}$ of $5^{\prime}-$ AAAAAAAUGC-3' template, and $1 \mathrm{mM}$ of the following nucleotide. Lane 1, none; lane 2, ATP; lane 3, 1a; lane 4, 2a; lane $5, \mathbf{3 a}$; lane $6, \mathbf{4 a}$; lane $7, \mathbf{5 a}$. The reaction products were resolved on a $25 \%$ polyacrylamide $-7 \mathrm{M}$ urea-TBE gel and were analyzed using a Phosphor Imager. The mobility of the radiolabeled dinucleotide primer and trinucleotide product was marked.

Table 2. Steady-State Kinetic Parameters for ATP and Adenosine Phosphono Diphosphates 1a-5a in an NS5B RdRp Catalyzed Nucleotide Incorporation Assay ${ }^{a}$

\begin{tabular}{lcccc}
\hline compd & $K_{\mathrm{i}}(\mu \mathrm{M})$ & $K_{\mathrm{m}}(\mu \mathrm{M})$ & $V_{\max }(\mu \mathrm{M} / \mathrm{min})$ & $V_{\max } / K_{\mathrm{m}}\left(\times 10^{3}\right)$ \\
\hline ATP & & $133 \pm 12$ & $0.23 \pm 0.07$ & $1.7 \pm 0.5$ \\
$\mathbf{1 a}$ & $201 \pm 47$ & & & \\
$\mathbf{2 a}$ & & $143 \pm 24$ & $0.028 \pm 0.002$ & $0.19 \pm 0.03$ \\
$\mathbf{3 a}$ & & $241 \pm 21$ & $0.0029 \pm 0.0001$ & $0.012 \pm 0.001$ \\
4a & $229 \pm 28$ & & & \\
$\mathbf{5 a}$ & $327 \pm 64$ & & & \\
\hline
\end{tabular}

${ }^{a}$ The reported data are an average of at least two sets of results.

ATP for NS5B RdRp. To determine their incorporation efficiency $\left(V_{\max } / K_{\mathrm{m}}\right)$, steady-state kinetic analysis was performed. The apparent $K_{\mathrm{m}}$ and $V_{\max }$ for $\mathbf{2 a}, \mathbf{3 a}$, and ATP were obtained at the fixed concentration of the template and primer $(20 \mu \mathrm{M})$, and their incorporation efficiency was calculated. Conversely, for compounds 1a, $\mathbf{4 a}$, and $\mathbf{5 a}$, which cannot be utilized as a substrate for NS5B RdRp, we determined their inhibition constant $\left(K_{\mathrm{i}}\right)$ against ATP through a Dixon plot. All the obtained kinetic parameters are summarized in Table 2. For compound $\mathbf{2 a}$, its $K_{\mathrm{m}}$ value is very similar to that of ATP, but its $V_{\max }$ is 10 -fold lower, resulting in an incorporation efficiency of $1.9 \times 10^{-4} \mathrm{~min}^{-1}$. These kinetic results suggest that the presence of the $5^{\prime}$-oxygen does not contribute much to the binding to NS5B RdRp $\left(K_{\mathrm{m}}\right)$, but it is critical for catalysis $\left(V_{\max }\right)$. Compound 3a has a lower incorporation efficiency than that of $\mathbf{2 a}$ with a $V_{\max }$ of $0.0029 \mu \mathrm{M} / \mathrm{min}$ and $K_{\mathrm{m}}$ around $241 \mu \mathrm{M}$. Compared to ATP, its $V_{\max }$ value is reduced by almost 100 -fold. Its incorporation efficiency of $1.2 \times 10^{-5} \mathrm{~min}^{-1}$ is 140-fold lower than that of ATP (Table 2). Apparently, the exchange of 5'-oxygen and -carbon has a relatively small effect on substrate binding but a severe consequence on catalysis. Intriguingly, although compounds 1a, 4a, and 5a are structurally similar to ATP, they cannot be utilized as a substrate for NS5B RdRp. Therefore, the structural alternations of removal of the 5 '-oxygen (1a) or ribose bridge oxygen $(\mathbf{4 a})$ and addition of a 2 -methyl group (5a) are detrimental to the activity of an adenosine phosphonate.

We further evaluated $\mathbf{2 a}$ and $\mathbf{3 a}$ as a potential chain terminator and investigated whether a trinucleotide ended by $\mathbf{2}$ or $\mathbf{3}$ can be further elongated by supplying the next elongating nucleotide UTP in the incorporation experiments described above. We were unable to detect any extended products in these experiments (data not shown). This could attribute to the fact that these two nucleoside phosphonates are functioning as a chain terminator. Although they possess the 3 '-hydroxyl group for elongation, the conformation distortion relayed from the phosphonate bond could prevent them from further chain elongation. Nucleoside analogues that retain a 3'hydroxyl have been reported as a chain terminator, such as 2 '-methyl $\mathrm{ATP}^{16}$ for HCV NS5B RdRp, and arabinosyladenine triphosphate ${ }^{27}$ and arabinofuranosylcytidine triphosphate ${ }^{28}$ for DNA polymerase $\beta$. Nevertheless, there is a slight possibility that a lower concentration of trinucleotides formed in the reaction makes any chain elongation difficult to detect under the described assay conditions. Further in vitro experiments using the chemical synthesized primers 3 -ended with $\mathbf{2}$ or $\mathbf{3}$ are needed to confirm the conclusion.

Inhibition experiments for compounds 1a, $\mathbf{4 a}$, and $\mathbf{5 a}$ were performed to determine whether they can compete with ATP to inhibit NS5B RdRp activity. All of them were found to behave as a competitive inhibitor against ATP (data not shown). Further kinetic analysis determined their apparent $K_{\mathrm{i}}$ values from Dixon plots at the fixed concentration of ATP $(1 \mathrm{mM})$ (Table 2). The $K_{\mathrm{i}}$ values range from 200 to $300 \mu \mathrm{M}$, which are about 1.52.5 -fold higher than $K_{\mathrm{m}}$ for ATP. These results suggest that all three compounds are capable of interacting with NS5B RdRp directly. However, their apparent binding affinity is weaker than that of endogenous ATP.

\section{Discussion}

The concept of nucleoside phosphonate chain terminator has been successfully utilized in designing novel and potent drugs against retroviruses. Notably, tenofovir disoproxil fumarate, a prodrug of PMPA; adefovir dipivoxil, a prodrug of PMEA; and cidofovir have been approved by the FDA for the treatment of HIV/AIDS, $\mathrm{HBV}$, and CMV infections, respectively. In this study, we extended the idea to HCV, an RNA virus. In this regard, a series of five adenosine phosphonate analogues were conceived and synthesized (Figure 2). They exhibited varied antiviral activity in an HCV replicon assay with an $\mathrm{EC}_{50}$ ranging from 35 to $200 \mu \mathrm{M}$. To eliminate the potential cell penetration issue associated with the anionic phosphonate moiety, we further modified compound 5 by masking its anionic charges with two SATE groups and prepared a bis-SATE prodrug $\mathbf{5 b}$. Compared to $\mathbf{5}$, the anti-HCV activity of $\mathbf{5 b}$ is moderately improved. But its cytotoxicity is drastically increased. The result is not totally unexpected. It implicates that the nucleoside phosphonate $\mathbf{5}$ may possess a broad activity against host polymerases. The cytotoxicity is exposed once it gets efficiently delivered into cells.

To understand the mechanism of action of these adenosine phosphonates, their diphosphate derivatives were synthesized so that they could be tested in an HCV NS5B RdRp catalyzed nucleotide incorporation assay. Among the five adenosine phosphono diphosphates, only 2a and 3a were incorporated by NS5B RdRp, implying that they can potentially serve as chain terminators. Their incorporation efficiency varies, providing an interesting structure-activity relationship (SAR). The 
$V_{\max } / K_{\mathrm{m}}$ for $\mathbf{2 a}$ and $\mathbf{3 a}$ is $10-100$-fold lower than that of ATP, respectively. Therefore, the substitution of 5'oxygen by a methylene or exchange of the $5^{\prime}$-carbon and -oxygen position of ATP not only does not potentiate but actually reduces a nucleotide's capability as a chain terminator. Similar results have been observed for the phosphonate analogues of AZTTP in the HIV-RT catalyzed reaction. ${ }^{29}$ Isosteric substitution of the $5^{\prime}$-oxygen by methylene for AZTTP reduces the catalytic efficiency of HIV-RT by 1800 -fold. The same substitution for ddUTP makes it a very poor substrate of HIV-RT. ${ }^{30}$

The failure of three other phosphono diphosphates, 1a, $\mathbf{4 a}$, and $\mathbf{5 a}$, to be accepted as a substrate by NS5B RdRp highlights the other key structural features required by a nucleotide chain terminator. A structural comparison of $1 \mathbf{a}$ to $\mathbf{2 a}, \mathbf{3 a}$ to $4 \mathbf{a}$, and $\mathbf{2 a}$ to $\mathbf{5 a}$ respectively suggests that shortening spacing between the 5'-carbon to phosphorus, replacement of the ribose bridge oxygen by a carbon, or addition of a 2 '-methyl group is detrimental for a phosphonate to function as a chain terminator. The incompetency of these nucleoside phosphonates can be further comprehended in the light of steady-state kinetics. As determined in this study, the $K_{\mathrm{m}}$ or $K_{\mathrm{i}}$ values are relatively unchanged for all five phosphono diphosphates compared to ATP's (Table 2). But their $V_{\max }$ are greatly diminished. As a result, the presence of a phosphonate linkage has a negligible effect on binding affinity but a severe consequence on catalytic efficiency. Such a reduction in the catalytic rate by the employment of a phosphonate analogue has been reported for AZTTP on HIV-RT. ${ }^{29}$ Conversely, these results are quite different from the published kinetic analysis of PMPA. ${ }^{10}$ PMPA is an acyclic nucleoside analogue that structurally differs from canonical nucleotides. Interestingly, its diphosphate derivative is comparable to ATP as a substrate for HIV-RT. It is likely that the acyclic sugar moiety in PMPA is flexible enough for the polymerase complex to bring the $\alpha$-phosphorus of PMPA to the 3'-OH of the primer in a productive orientation. In contrast, the relatively rigid ribose ring in our compounds or in the phosphonate analogue of AZTTP and ddUTP might render a higher energy barrier for formation of a productive complex between polymerase and a nucleotide. Consistent with this argument is the observation that shortening the length between the $\alpha$-phosphorus and ribose or employing a carbocyclic ring was more detrimental to polymerase function than isosteric exchanges. It will be a challenge to design a PMEA- or PMPA-like acyclic nucleoside phosphonate analogue for an RNA virus, since an RNA polymerase requires the 2 '-OH of the ribose ring for proper substrate recognition and there is no simple solution to retain the 2 '-OH moiety in an acyclic nucleoside.

In summary, several adenosine phosphonate analogues were successfully synthesized. These AMP mimics demonstrated some promising but relatively weak anti-HCV activity. Further mechanistic studies indicate that compounds $\mathbf{2 a}$ and $\mathbf{3 a}$ can potentially function as a chain terminator, thereby proving the principle that the nucleoside phosphonate concept is applicable to an RNA virus. But challenges remain as neither $\mathbf{2 a}$ nor 3a are potent enough to compete with ATP. The structural modifications on the ribose and around the 5'-moiety in this study are not adequate to improve a chain terminator's catalytic efficiency nor the binding affinity to NS5B RdRp. Further medicinal chemistry efforts are needed to come up with novel and potent nucleoside phosphonate chain terminators for HCV.

\section{Experimental Section}

General Chemical Methods. ${ }^{1} \mathrm{H}$ NMR spectra were recorded on a Varian Mercury 300 spectrometer with TMS as the internal standard. Mass spectral data were obtained on an API 150EX electrospray mass spectrometer. Anhydrous solvents were purchased from Acros or Fluka and were used without further treatment unless noted. TLC plates and silica gel for flash chromatography were supplied by ICN Biomedicals or Fisher Scientific. Solvent ratios were based on volume in case that solvent mixture was used.

9-[5'-Deoxy-5'-[(hydroxypyrophosphoroxy)phosphinyl]$\beta$-D-ribo-furanosyl] adenine (1a). A solution of 9-[5'-deoxy5 '-(dihydroxyphosphinyl)- $\beta$-D-ribofuranosyl]adenine (1a) (19 $\mathrm{mg}, 0.059 \mathrm{mmol})$ and tributylamine $(100 \mu \mathrm{L}, 0.41 \mathrm{mmol})$ in water $(0.5 \mathrm{~mL})$ was evaporated under reduced pressure. The residue was repeatedly coevaporated with anhydrous ethanol and toluene. To the resulting powder were added DMF $(2 \mathrm{~mL})$ and 1,1' ${ }^{\prime}$-carbonyldiimidazole (64 $\left.\mathrm{mg}, 0.39 \mathrm{mmol}\right)$. After stirring at room temperature for $3.5 \mathrm{~h}$, the reaction was quenched by addition of methanol $(20 \mu \mathrm{L})$. Bis(tri-n-butylammonium)pyrophosphate (153 mg, $0.34 \mathrm{mmol}$ ) was added, and the stirring was continued for $16 \mathrm{~h}$. White precipitate was removed by centrifugation. The supernatant was collected and concentrated under reduced pressure. The resulting residue was dissolved in $1 \mathrm{M}$ solution of triethylammonium bicarbonate buffer ( $3 \mathrm{~mL}, \mathrm{pH}=8.5)$ and stirred at room temperature for $2 \mathrm{~h}$. The mixture was concentrated under reduced pressure. It was purified by RP-HPLC $(250 \times 10 \mathrm{~mm}$, YMC-Pack ODS$\mathrm{AQ}$, Waters) with a linear gradient of acetonitrile from 0 to $20 \%$ (for $60 \mathrm{~min}$ ) in $50 \mathrm{mM}$ tetraethylammonium acetate buffer (TEAA, pH 7.0, $\left.t_{\mathrm{R}}=22 \mathrm{~min}\right)$. The yield was $7.2 \mathrm{mg}(25 \%)$ of 1a. ${ }^{1} \mathrm{H}$ NMR $\left(\mathrm{D}_{2} \mathrm{O}\right): \delta 8.25(\mathrm{~s}, 1 \mathrm{H}), 8.08(\mathrm{~s}, 1 \mathrm{H}), 5.89(\mathrm{~d}, J=$ $6.0 \mathrm{~Hz}, 1 \mathrm{H}), 4.65(\mathrm{~m}, 1 \mathrm{H}), 4.27(\mathrm{~m}, 2 \mathrm{H}), 3.02(\mathrm{q}, J=7.5 \mathrm{~Hz}$, $36 \mathrm{H}), 2.20(\mathrm{~m}, 2 \mathrm{H}), 1.10(\mathrm{t}, J=7.5 \mathrm{~Hz}, 48 \mathrm{H}) .{ }^{31} \mathrm{P}$ NMR $\left(\mathrm{D}_{2} \mathrm{O}\right)$ : $\delta 13.2,-9.79,-22.2$. MS (ES): $m / e 489.6(\mathrm{M}-\mathrm{H})$.

9-[5',6'-Dideoxy-6'-(hydroxyphosphinyl)- $\beta$-D-ribo-hexofuranosyl]adenine (2). A solution of 8 (190 $\mathrm{mg}, 0.30 \mathrm{mmol}$ ) in methanolic ammonia $\left(40 \mathrm{~mL}\right.$, saturated at $\left.0{ }^{\circ} \mathrm{C}\right)$ was stirred at room temperature in a sealed bomb for $24 \mathrm{~h}$. The bomb was cooled to $0{ }^{\circ} \mathrm{C}$ before opening. The reaction mixture was stirred at room temperature for $1 \mathrm{~h}$ and then concentrated to dryness. Silica gel chromatography $\left(\mathrm{CH}_{2} \mathrm{Cl}_{2}: \mathrm{MeOH}=90: 10\right)$ yielded 146 $\mathrm{mg}(92 \%)$ of 9 -[5', $6^{\prime}$-dideoxy- $6^{\prime}$-(dibenzyloxyphosphinyl)- $\beta$-Dribo-hexofuranosyl] adenine as a pale foam. To a solution of the compound obtained above (146 mg, $0.28 \mathrm{mmol})$ in $\mathrm{MeOH}$ $(20 \mathrm{~mL})$ was added $\mathrm{Pd}-\mathrm{C}(10 \%, 150 \mathrm{mg})$. The reaction mixture was stirred under atmospheric pressure of hydrogen. After 16 $\mathrm{h}$, the mixture was filtered through Celite to remove the catalyst. The filter cake was washed with $\mathrm{H}_{2} \mathrm{O}(20 \mathrm{~mL})$ and the combined filtrate was evaporated to dryness. The resulting solid obtained was washed with $\mathrm{CH}_{2} \mathrm{Cl}_{2}(1 \mathrm{~mL})$ to yield $53 \mathrm{mg}$ $(55 \%)$ of 2 as a white solid. ${ }^{1} \mathrm{H}$ NMR (DMSO- $\left.d_{6}\right): \delta 8.41(\mathrm{~s}$, $1 \mathrm{H}), 8.25(\mathrm{~s}, 1 \mathrm{H}), 7.38(\mathrm{br} \mathrm{s}, 2 \mathrm{H}), 5.94(\mathrm{~d}, J=4.5 \mathrm{~Hz}, 1 \mathrm{H}), 4.69$ $(\mathrm{m}, 1 \mathrm{H}), 4.16(\mathrm{~m}, 1 \mathrm{H}), 3.98(\mathrm{~m}, 1 \mathrm{H}), 1.94(\mathrm{~m}, 2 \mathrm{H}), 1.59(\mathrm{~m}$, $2 \mathrm{H})$. HRMS $(\mathrm{M}+\mathrm{H})^{+}$for $\mathrm{C}_{11} \mathrm{H}_{16} \mathrm{~N}_{5} \mathrm{O}_{6} \mathrm{P}$ : calcd $\mathrm{m} / z$ 346.0916, obs 346.0905 .

9-[5',6'-Dideoxy-6'-[(hydroxypyrophosphoroxy)phosphinyl]- $\beta$-D-ribo-hexofuranosyl]adenine (2a). Diphosphate $\mathbf{2 a}\left(8.0 \mathrm{mg}, 28 \%, t_{\mathrm{R}}=22 \mathrm{~min}\right)$ was prepared from $2(19 \mathrm{mg}$, $0.056 \mathrm{mmol}$ ) by a similar procedure as that described for the synthesis of 1a. ${ }^{1} \mathrm{H}$ NMR $\left(\mathrm{D}_{2} \mathrm{O}\right): \delta 8.23(\mathrm{~s}, 1 \mathrm{H}), 8.09(\mathrm{~s}, 1 \mathrm{H})$, $5.89(\mathrm{~d}, J=6.3 \mathrm{~Hz}, 1 \mathrm{H}), 4.60(\mathrm{~m}, 1 \mathrm{H}), 4.14(\mathrm{dd}, J=3.6,5.4$ $\mathrm{Hz}, 1 \mathrm{H}), 4.04(\mathrm{~m}, 1 \mathrm{H}), 3.02(\mathrm{q}, J=7.5 \mathrm{~Hz}, 36 \mathrm{H}), 1.88(\mathrm{~m}, 2 \mathrm{H})$, $1.73(\mathrm{~m}, 2 \mathrm{H}), 1.10(\mathrm{t}, J=7.5 \mathrm{~Hz}, 48 \mathrm{H}) .{ }^{31} \mathrm{P} \mathrm{NMR}\left(\mathrm{D}_{2} \mathrm{O}\right): \delta$ 19.6, -9.85, -22.3. MS (ES): m/e 503.6 (M - H).

$(2 R, 3 R, 4 S, 5 R)-9$-[Tetrahydro-3,4-dihydroxy-5-[(hydroxylpyrophosphoroxy)phosphonomethoxy]-2-furanyl]ad- 
enine (3a). Diphosphate 3a (16 mg, 35\%, $\left.t_{\mathrm{R}}=20 \mathrm{~min}\right)$ was prepared from $(2 R, 3 R, 4 S, 5 R)$-9-[tetrahydro-3,4-dihydroxy-5(phosphonomethoxy)-2-furanyl]adenine (3) (50 mg, $0.091 \mathrm{mmol}$ ) by a similar procedure as that described for the synthesis of 1a. ${ }^{1} \mathrm{H}$ NMR $\left(\mathrm{D}_{2} \mathrm{O}\right): \delta 8.35(\mathrm{~s}, 1 \mathrm{H}), 8.13(\mathrm{~s}, 1 \mathrm{H}), 6.08(\mathrm{~d}, J=$ $6.6 \mathrm{~Hz}, 1 \mathrm{H}), 5.12(\mathrm{~s}, 1 \mathrm{H}), 4.89(\mathrm{dd}, J=4.5,6.6 \mathrm{~Hz}, 1 \mathrm{H}), 4.27$ (d, $J=4.5 \mathrm{~Hz}, 1 \mathrm{H}), 3.79$ (dd, $J=9.0,13.2 \mathrm{~Hz}, 1 \mathrm{H}), 3.67$ (dd, $J=10.2,13.2 \mathrm{~Hz}, 1 \mathrm{H}), 3.02(\mathrm{q}, J=7.5 \mathrm{~Hz}, 36 \mathrm{H}), 1.11(\mathrm{t}, J=$ $7.5 \mathrm{~Hz}, 48 \mathrm{H}) .{ }^{31} \mathrm{P} \mathrm{NMR}\left(\mathrm{D}_{2} \mathrm{O}\right): \delta 8.5,-9.87,-22.4 . \mathrm{MS}(\mathrm{ES})$ : m/e $505.6(\mathrm{M}-\mathrm{H})$.

$(1 R, 2 R, 3 S, 4 S)-9-[2,3-D i h y d r o x y-4$-(phosphonomethoxy)cyclopent-1-yl]adenine (4). To a solution of $12(40 \mathrm{mg}$, $0.10 \mathrm{mmol}$ ) in DMF (4 mL) was added bromotrimethylsilane $(0.5 \mathrm{~mL})$ at $0{ }^{\circ} \mathrm{C}$. The reaction mixture was slowly warmed to room temperature and stirred at the temperature for $6 \mathrm{~h}$. The volatiles were concentrated to dryness. The oil was diluted with concentrated $\mathrm{NH}_{4} \mathrm{OH}(1.5 \mathrm{~mL})$, which was subsequently evaporated to yield a white solid. It was purified by a $\mathrm{C}_{18}$ reverse-phase column chromatography with a gradient from $100 \%$ triethylammonium acetate buffer (TEAA buffer, $50 \mathrm{mM}$ ) to a mixture of $80 \%$ TEAA buffer and $20 \% \mathrm{CH}_{3} \mathrm{CN}$. The yield was $28 \mathrm{mg}(80 \%)$ of 4 as a white solid. ${ }^{1} \mathrm{H}$ NMR $\left(\mathrm{D}_{2} \mathrm{O}\right): \delta 8.11$ (s, 1H), $7.93(\mathrm{~s}, 1 \mathrm{H}), 4.59(\mathrm{~m}, 1 \mathrm{H}), 4.30(\mathrm{dd}, J=5.1,8.4 \mathrm{~Hz}$, $1 \mathrm{H}), 4.07(\mathrm{~d}, J=4.8 \mathrm{~Hz}, 1 \mathrm{H}), 3.83(\mathrm{~m}, 1 \mathrm{H}), 3.55(\mathrm{~d}, J=9.6$ $\mathrm{Hz}, 2 \mathrm{H}), 3.00$ (q, $J=7.2 \mathrm{~Hz}, 12 \mathrm{H}), 2.70(\mathrm{~m}, 1 \mathrm{H}), 1.88(\mathrm{~m}, 1 \mathrm{H})$, $1.09(\mathrm{t}, J=7.2 \mathrm{~Hz}, 18 \mathrm{H}) .{ }^{31} \mathrm{P} \mathrm{NMR}\left(\mathrm{D}_{2} \mathrm{O}\right): \delta 16.6$. HRMS $(\mathrm{M}$ $+\mathrm{H})^{+}$for $\mathrm{C}_{11} \mathrm{H}_{16} \mathrm{~N}_{5} \mathrm{O}_{6} \mathrm{P}$ : calcd $\mathrm{m} / z$ 346.0916, obs 346.0905.

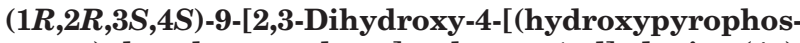
phoroxy)phosphonomethoxy]cyclopent-1-yl]adenine (4a). Diphosphate $4 \mathbf{a}\left(9.1 \mathrm{mg}, 47 \%, t_{\mathrm{R}}=27 \mathrm{~min}\right)$ was prepared from 4 (21 $\mathrm{mg}, 0.038 \mathrm{mmol}$ ) by a similar procedure as that described for the synthesis of 1a. ${ }^{1} \mathrm{H}$ NMR $\left(\mathrm{D}_{2} \mathrm{O}\right): \delta 8.30(\mathrm{~s}, 1 \mathrm{H}), 8.12(\mathrm{~s}$, $1 \mathrm{H}), 4.75(\mathrm{~m}, 1 \mathrm{H}), 4.51$ (dd, $J=4.8,8.4 \mathrm{~Hz}, 1 \mathrm{H}), 4.15(\mathrm{~d}, J=$ $6.0 \mathrm{~Hz}, 1 \mathrm{H}), 3.89(\mathrm{~m}, 1 \mathrm{H}), 3.75(\mathrm{dd}, J=3.9,9.6 \mathrm{~Hz}, 2 \mathrm{H}), 3.01$ $(\mathrm{m}, 36 \mathrm{H}), 2.75(\mathrm{~m}, 1 \mathrm{H}), 1.94(\mathrm{~m}, 1 \mathrm{H}), 1.01(\mathrm{~m}, 48 \mathrm{H}) .{ }^{31} \mathrm{P}$ NMR $\left(\mathrm{D}_{2} \mathrm{O}\right): \delta 9.58,-9.89,-22.2$. MS (ES): $m / e 503.6(\mathrm{M}+\mathrm{H})$.

9-[5',6'-Dideoxy-6'-(hydroxyphosphinyl)-2' $C$-methyl- $\beta$ D-ribo-hexofuranosyl]adenine (5). Compound $5(31 \mathrm{mg}$, $60 \%)$ was prepared from $15(123 \mathrm{mg}, 0.17 \mathrm{mmol})$ by a similar procedure as that described for the synthesis of $\mathbf{8}$ and $2 .{ }^{1} \mathrm{H}$ $\operatorname{NMR}\left(\mathrm{D}_{2} \mathrm{O}\right): \delta 8.17(\mathrm{~s}, 1 \mathrm{H}), 8.14(\mathrm{~s}, 1 \mathrm{H}), 5.94(\mathrm{~s}, 1 \mathrm{H}), 3.92(\mathrm{~m}$, $1 \mathrm{H}), 3.85(\mathrm{~d}, J=8.7 \mathrm{~Hz}, 1 \mathrm{H}), 1.95(\mathrm{~m}, 2 \mathrm{H}), 1.66(\mathrm{~m}, 2 \mathrm{H}), 0.79$ $(\mathrm{s}, 3 \mathrm{H}) .{ }^{31} \mathrm{P}$ NMR $\left(\mathrm{D}_{2} \mathrm{O}\right): \delta$ 26.1. HRMS $(\mathrm{M}+\mathrm{H})^{+}$for $\mathrm{C}_{12} \mathrm{H}_{18} \mathrm{~N}_{5} \mathrm{O}_{6} \mathrm{P}$ : calcd $\mathrm{m} / \mathrm{z} 360.1073$, obs 360.1085 .

tert-Butyl SATE Phosphodiester of 9-[5',6'-Dideoxy-6'(hydroxylphosphinyl)-2'-C-methyl- $\beta$-D-ribo-hexofuranosyl]adenine (5b). A solution of $\mathbf{1 9}(18 \mathrm{mg}, 0.032 \mathrm{mmol})$ and tributylamine $(25 \mu \mathrm{L}, 0.10 \mathrm{mmol})$ in methanol $(0.5 \mathrm{~mL})$ was evaporated under reduced pressure. The residue was repeatedly coevaporated with anhydrous ethanol and toluene. To the resulting oil were added pyridine $(2 \mathrm{~mL})$, thioester $16(100$ $\mathrm{mg}, 0.61 \mathrm{mmol}$ ), and 1-mestylene-2-sulfonyl-3-nitro-1,2,4triazole ( $38 \mathrm{mg}, 0.13 \mathrm{mmol}$ ). The reaction mixture was stirred at room temperature for $18 \mathrm{~h}$ and quenched by the addition of tetrabutylammonium bicarbonate buffer $(2 \mathrm{~mL}, 1 \mathrm{M}$ solution, $\mathrm{pH}$ 8.0). The mixture was extracted with $\mathrm{CHCl}_{3}(3 \times 10 \mathrm{~mL})$. The organic solution was washed with brine $(10 \mathrm{~mL})$, dried with $\mathrm{Na}_{2} \mathrm{SO}_{4}$, and concentrated to dryness to give the corresponding 3'-TBDMS nucleoside phosphonate. To the crude nucleoside in THF (3 mL) was added a mixture of tetrabutylammonium fluoride $(0.76 \mathrm{~mL}, 1 \mathrm{M}$ in THF, $0.76 \mathrm{mmol})$ and acetic acid $(0.04 \mathrm{~mL})$. The mixture was stirred at room temperature for $16 \mathrm{~h}$ and evaporated under reduced pressure. Silica gel chromatography (EtOAc: $\mathrm{MeOH}=95: 5)$ yielded 10 $\mathrm{mg}(49 \%)$ of 5b. ${ }^{1} \mathrm{H}$ NMR $\left(\mathrm{CD}_{3} \mathrm{OD}\right): \delta 8.21(\mathrm{~s}, 1 \mathrm{H}), 8.16(\mathrm{~s}$, $1 \mathrm{H}), 6.02(\mathrm{~s}, 1 \mathrm{H}), 4.11(\mathrm{~m}, 6 \mathrm{H}), 3.15(\mathrm{t}, J=6.6 \mathrm{~Hz}, 4 \mathrm{H}), 2.14$ $(\mathrm{m}, 4 \mathrm{H}), 1.22(\mathrm{~s}, 18 \mathrm{H}), 0.96(\mathrm{~s}, 3 \mathrm{H})$. HRMS $(\mathrm{M}+\mathrm{H})^{+}$for $\mathrm{C}_{26} \mathrm{H}_{42} \mathrm{~N}_{5} \mathrm{O}_{8} \mathrm{PS}_{2}$ : calcd $\mathrm{m} / \mathrm{z}$ 648.2290, obs 648.2306.

9-[5',6'-Dideoxy-6'-[(hydroxypyrophosphoroxy)phosphinyl]-2' $C$-methyl- $\beta$-D-ribo-hexofuranosyl]adenine (5a). Compound $\mathbf{5 a}\left(6.8 \mathrm{mg}, 21 \%, t_{\mathrm{R}}=27 \mathrm{~min}\right)$ was prepared from 5 (22 $\mathrm{mg}, 0.061 \mathrm{mmol}$ ) by a similar procedure as that described for the synthesis of 1a. ${ }^{1} \mathrm{H} \mathrm{NMR}\left(\mathrm{D}_{2} \mathrm{O}\right): \delta 8.13(\mathrm{~s}, 2 \mathrm{H}), 5.95(\mathrm{~s}$, $1 \mathrm{H}), 3.94(\mathrm{~s}, 1 \mathrm{H}), 3.85(\mathrm{~d}, J=8.7 \mathrm{~Hz}, 1 \mathrm{H}), 3.02(\mathrm{q}, J=7.5 \mathrm{~Hz}$,
$36 \mathrm{H}), 2.00$ (m, 4H), 1.11 (t, $J=7.5 \mathrm{~Hz}, 48 \mathrm{H}), 0.79(\mathrm{~s}, 3 \mathrm{H}),{ }^{31} \mathrm{P}$ NMR $\left(\mathrm{D}_{2} \mathrm{O}\right): \delta 19.2,-10.3,-23.2$. HRMS $(\mathrm{M}+\mathrm{H})^{+}$for $\mathrm{C}_{12} \mathrm{H}_{18} \mathrm{~N}_{5} \mathrm{O}_{6} \mathrm{P}$ : calcd $\mathrm{m} / \mathrm{z} 360.1073$, obs 360.1085 .

$N^{6}$-Benzoyl-9-[2',3'-di-O-benzoyl-5',6'-dideoxy-6'-(diphenoxyphosphinyl)- $\beta$-D-ribohexofuranosyl]adenine (7). Trifluoroacetic acid $(0.15 \mathrm{~mL})$ was added to a solution of $N^{6}$ benzoyl-9-( $2^{\prime}, 3^{\prime}$-di- $O$-benzoyl- $\beta$-D-ribofuranosyl)adenine (6) (1.65 $\mathrm{g}, 2.8 \mathrm{mmol}), 1,3$-dicyclohexylcarbodiimide $(2.34 \mathrm{~g}, 11.4 \mathrm{mmol})$, and pyridine $(0.32 \mathrm{~mL})$ in anhydrous DMSO $(15 \mathrm{~mL})$. The mixture was stirred at room temperature for $22 \mathrm{~h}$. To the mixture was added diphenyl(triphosphoranylidene)methylphosphonate $(2.89 \mathrm{~g}, 5.7 \mathrm{mmol})$ and stirring was continued for $24 \mathrm{~h}$. Excess carbodiimide was hydrolyzed by a careful addition of a solution of oxalic acid dihydrate $(771 \mathrm{mg}, 8.6 \mathrm{mmol})$ in $\mathrm{MeOH}(3 \mathrm{~mL})$. After stirring for $10 \mathrm{~min}$, the volatiles were removed under reduced pressure, and the formed urea was removed by vacuum filtration. The filtrate was extracted with EtOAc $(300 \mathrm{~mL})$. The organic solution was washed with brine $(2 \times 100 \mathrm{~mL})$, dried with $\mathrm{Na}_{2} \mathrm{SO}_{4}$, and concentrated to dryness. Silica gel chromatography (EtOAc) yielded $1.43 \mathrm{~g}(62 \%)$ of $N^{6}$ benzoyl-9-[2',3'-di-O-benzoyl-5',6'-dideoxy-6'-(diphenoxyphosphinyl)- $\beta$-D-ribo-hex-5-enofuranosyl]adenine. To a solution of the vinyl phosphonate $(654 \mathrm{mg}, 0.81 \mathrm{mmol})$ in $\mathrm{MeOH}(20 \mathrm{~mL})$ was added $\mathrm{Pd}-\mathrm{C}(10 \%, 200 \mathrm{mg})$. The reaction mixture was stirred under $30 \mathrm{psi}$ of hydrogen. After $20 \mathrm{~h}$, the mixture was filtered through Celite to remove the catalyst, and the filtrate was evaporated to dryness. Silica gel chromatography (EtOAc: hexanes $=75: 25)$ yielded $505 \mathrm{mg}(77 \%)$ of 7. ${ }^{1} \mathrm{H}$ NMR (DMSO$\left.d_{6}\right): \delta 11.3(\mathrm{br} \mathrm{s}, 1 \mathrm{H}), 8.76(\mathrm{~s}, 1 \mathrm{H}), 8.74(\mathrm{~s}, 1 \mathrm{H}), 8.06-7.13(\mathrm{~m}$, $25 \mathrm{H}), 6.61(\mathrm{~d}, J=5.1 \mathrm{~Hz}, 1 \mathrm{H}), 6.46(\mathrm{dd}, J=5.1,5.4 \mathrm{~Hz}, 1 \mathrm{H})$, $5.99(\mathrm{t}, J=5.7 \mathrm{~Hz}, 1 \mathrm{H}), 4.61(\mathrm{~d}, J=5.4 \mathrm{~Hz}, 1 \mathrm{H}), 2.37(\mathrm{~m}$, $4 \mathrm{H})$.

$N^{6}$-Benzoyl-9-[5',6'-dideoxy-6'-(dibenzyloxyphosphinyl)$\boldsymbol{\beta}$-D-ribo-hexofuranosyl]adenine (8). Sodium hydride (200 $\mathrm{mg}, 5.0 \mathrm{mmol}$ ) was added to $4 \mathrm{~mL}$ of benzyl alcohol. The resulting suspension was stirred for $30 \mathrm{~min}$. To the mixture was added a solution of 7 (720 $\mathrm{mg}, 0.88 \mathrm{mmol})$ in anhydrous DMSO $(4 \mathrm{~mL})$. The reaction was stirred at room temperature for $4 \mathrm{~h}$ and quenched with saturated $\mathrm{NH}_{4} \mathrm{Cl}$ solution $(20 \mathrm{~mL})$. The mixture was extracted with EtOAc $(2 \times 60 \mathrm{~mL})$. The combined organic solution was washed with brine $(60 \mathrm{~mL})$, dried with $\mathrm{Na}_{2} \mathrm{SO}_{4}$, and concentrated to dryness. Silica gel chromatography (EtOAc: $\mathrm{MeOH}=90: 10)$ yielded $420 \mathrm{mg}(75 \%)$ of 8. ${ }^{1} \mathrm{H}$ NMR (DMSO- $\left.d_{6}\right): \delta 11.2(\mathrm{br} \mathrm{s}, 1 \mathrm{H}), 8.67(\mathrm{~s}, 1 \mathrm{H}), 8.66$ (s, $1 \mathrm{H}), 8.03(\mathrm{~d}, J=7.5 \mathrm{~Hz}, 2 \mathrm{H}), 7.60(\mathrm{~m}, 3 \mathrm{H}), 7.33(\mathrm{~m}, 10 \mathrm{H})$, $5.96(\mathrm{~d}, J=5.4 \mathrm{~Hz}, 1 \mathrm{H}), 5.54(\mathrm{~d}, J=5.7 \mathrm{~Hz}, 1 \mathrm{H}), 5.27(\mathrm{~d}, J=$ $5.4 \mathrm{~Hz}, 1 \mathrm{H}), 4.96(\mathrm{~m}, 4 \mathrm{H}), 4.73(\mathrm{q}, J=5.4 \mathrm{~Hz}, 1 \mathrm{H}), 4.10(\mathrm{~m}$, $1 \mathrm{H}), 3.91(\mathrm{~m}, 1 \mathrm{H}), 1.91(\mathrm{~m}, 4 \mathrm{H})$.

$(1 R, 4 S)-N$-[9-(4-Hydroxycyclopent-2-en-1-yl)-9H-purin6-yl]- $\boldsymbol{N}, \boldsymbol{N}$-dimethylformamidine (10). To a solution of a $(1 R, 4 S)-9$-(4-hydroxycyclopent-2-en-1-yl)adenine (9) $(400 \mathrm{mg}$, $1.8 \mathrm{mmol})$ in DMF (10 mL) was added $N, N$-diethylformamide diethyl acetal $(0.47 \mathrm{~mL}, 2.8 \mathrm{mmol})$. After stirring at room temperature for $5 \mathrm{~h}$, the mixture was evaporated under reduced pressure. Silica gel chromatography $\left(\mathrm{CH}_{2} \mathrm{Cl}_{2}: \mathrm{MeOH}\right.$ $=90: 10)$ yielded $491 \mathrm{mg}(98 \%)$ of $10 .{ }^{1} \mathrm{H}$ NMR $\left(\mathrm{CD}_{3} \mathrm{OD}\right): \delta$ $8.91(\mathrm{~s}, 1 \mathrm{H}), 8.43(\mathrm{~s}, 1 \mathrm{H}), 8.24(\mathrm{~s}, 1 \mathrm{H}), 6.29(\mathrm{~m}, 1 \mathrm{H}), 6.05(\mathrm{~m}$, $1 \mathrm{H}), 5.60(\mathrm{~m}, 1 \mathrm{H}), 4.85(\mathrm{~m}, 1 \mathrm{H}), 3.30(\mathrm{~s}, 6 \mathrm{H}), 3.06(\mathrm{td}, J=7.8$, $15 \mathrm{~Hz}, 1 \mathrm{H}), 1.90(\mathrm{td}, J=3.6,15 \mathrm{~Hz}, 1 \mathrm{H})$.

$(1 R, 4 S)-9-[4-(D i e t h y l p h o s p h o n o m e t h o x y)-2,3-d i-$ hydroxycyclopent-2-en-1-yl]adenine (12). To a solution of $10(271 \mathrm{mg}, 1.0 \mathrm{mmol})$ and $\mathrm{NaH}(76 \mathrm{mg}, 1.9 \mathrm{mmol})$ in DMF $(10 \mathrm{~mL})$ at $0{ }^{\circ} \mathrm{C}$ was added diethyl $p$-toluenesulfonoxymethyl phosphanate (11) $(610 \mathrm{mg}, 1.9 \mathrm{mmol})$. The reaction was slowly warmed to room temperature and stirred for $16 \mathrm{~h}$. The mixture was neutralized with acetic acid, and the volatiles were concentrated to dryness. The crude mixture was dissolved in methanolic ammonia $\left(40 \mathrm{~mL}\right.$, saturated at $\left.0{ }^{\circ} \mathrm{C}\right)$ and stirred at room temperature in a sealed bomb for $24 \mathrm{~h}$. The bomb was cooled to $0{ }^{\circ} \mathrm{C}$ before opening, and the reaction mixture was concentrated to dryness. Silica gel chromatography $\left(\mathrm{CH}_{2} \mathrm{Cl}_{2}\right.$ : $\mathrm{MeOH}=95: 5$ ) yielded $147 \mathrm{mg}$ of a cyclopentene intermediate. The material was dissolved in a mixture of acetone $(6 \mathrm{~mL})$, $t$-BuOH $(1 \mathrm{~mL})$, and $\mathrm{H}_{2} \mathrm{O}(1 \mathrm{~mL})$ along with 4-methylmorpho- 
rine $N$-oxide $(0.10 \mathrm{~mL}, 0.60 \mathrm{mmol})$. Subsequently, $\mathrm{OsO}_{4}(0.24$ $\mathrm{mL}, 0.020 \mathrm{mmol}$ ) was added. The reaction mixture was stirred at room temperature for $16 \mathrm{~h}$, and the volatiles were concentrated to dryness. Silica gel chromatography $\left(\mathrm{CH}_{2} \mathrm{Cl}_{2}: \mathrm{MeOH}\right.$ $=95: 5)$ yielded $96 \mathrm{mg}(24 \%$ from 10 $)$ of $12 .{ }^{1} \mathrm{H} \mathrm{NMR}\left(\mathrm{CD}_{3} \mathrm{OD}\right)$ : $\delta 8.22(\mathrm{~s}, 1 \mathrm{H}), 8.17(\mathrm{~s}, 1 \mathrm{H}), 4.86(\mathrm{~m}, 1 \mathrm{H}), 4.59(\mathrm{dd}, J=4.8,8.1$ $\mathrm{Hz}, 1 \mathrm{H}), 4.20(\mathrm{~m}, 5 \mathrm{H}), 3.99(\mathrm{~d}, J=9.3 \mathrm{~Hz}, 2 \mathrm{H}), 3.95(\mathrm{~m}, 1 \mathrm{H})$, $2.82(\mathrm{~m}, 1 \mathrm{H}), 2.17(\mathrm{~m}, 1 \mathrm{H}), 1.37$ (t, $J=6.0 \mathrm{~Hz}, 6 \mathrm{H}) .{ }^{31} \mathrm{P}$ NMR $\left(\mathrm{CD}_{3} \mathrm{OD}\right): \delta 23.0$.

$N^{6}$-Dibenzoyl-9-(3'-O-benzoyl-2' $C$-methyl- $\beta$-D-ribofuranosyl)adenine (14). To a solution of $\mathbf{1 3}$ (1.20 g, $4.2 \mathrm{mmol})$ in DMF $(10 \mathrm{~mL})$ and pyridine $(40 \mathrm{~mL})$ was added tertbutyldimethylsilyl chloride $(633 \mathrm{mg}, 4.2 \mathrm{mmol})$. The reaction mixture was stirred at room temperature for $24 \mathrm{~h}$ and quenched by addition of methanol $(1 \mathrm{~mL})$. The mixture was evaporated under reduced pressure and diluted with $\mathrm{CH}_{2} \mathrm{Cl}_{2}$ $(100 \mathrm{~mL})$. The solution was washed with aqueous $\mathrm{NaHCO}_{3}$ solution $(50 \mathrm{~mL})$ and brine $(50 \mathrm{~mL})$. It was then dried with $\mathrm{Na}_{2} \mathrm{SO}_{4}$ and concentrated to dryness to give the corresponding $5^{\prime}$-TBDMS nucleoside. To the crude nucleoside in pyridine (50 $\mathrm{mL}$ ) was added benzoic anhydride ( $3.80 \mathrm{~g}, 16.8 \mathrm{mmol})$. The mixture was heated at $100{ }^{\circ} \mathrm{C}$ for $16 \mathrm{~h}$, cooled to room temperature, and quenched by the addition of methanol (2 $\mathrm{mL}$ ). The mixture was evaporated under reduced pressure and diluted with $\mathrm{CH}_{2} \mathrm{Cl}_{2}(100 \mathrm{~mL})$. The solution was washed with aqueous $\mathrm{NaHCO}_{3}$ solution $(50 \mathrm{~mL})$ and brine $(50 \mathrm{~mL})$, dried over $\mathrm{Na}_{2} \mathrm{SO}_{4}$, and concentrated to dryness. Silica gel chromatography (EtOAc:hexanes $=40: 60)$ yielded $2.05 \mathrm{~g} \mathrm{(69 \%} \mathrm{from}$ 13) of $N^{6}$-dibenzoyl- $9 H$-(3'-O-benzoyl-5'-O-tert-butyldimethylsilyl-2'-C-methyl- $\beta$-D-ribofuranosyl)adenine. To this nucleoside (448 mg, $0.63 \mathrm{mmol})$ in THF $(10 \mathrm{~mL})$ was added a mixture of tetrabutylammonium fluoride $(0.76 \mathrm{~mL}, 1 \mathrm{M}$ in THF, 0.76 $\mathrm{mmol})$ and acetic acid $(0.04 \mathrm{~mL})$. The mixture was stirred at room temperature for $16 \mathrm{~h}$ and evaporated under reduced pressure. Silica gel chromatography (EtOAc:hexanes $=50: 50)$ yielded $250 \mathrm{mg}(67 \%)$ of $14 .{ }^{1} \mathrm{H}$ NMR $\left(\mathrm{DMSO}-d_{6}\right): \delta 9.03(\mathrm{~s}$, $1 \mathrm{H}), 8.73(\mathrm{~s}, 1 \mathrm{H}), 8.07-7.42(\mathrm{~m}, 15 \mathrm{H}), 6.18(\mathrm{~s}, 1 \mathrm{H}), 6.04(\mathrm{~s}$, $1 \mathrm{H}), 5.57(\mathrm{~d}, J=8.7 \mathrm{~Hz}, 1 \mathrm{H}), 5.34(\mathrm{t}, J=4.8 \mathrm{~Hz}, 1 \mathrm{H}), 4.40$ (m, 1H), 3.88-3.67 (m, 2H), 0.90 (s, 3H). MS (ES): $m / e 594.2$ $(\mathrm{M}+\mathrm{H})$.

$N^{6}$-Benzoyl-9-[3'-O-benzoyl-5',6'-dideoxy-6'-(diphenoxyphosphinyl)-2' $C$-methyl- $\beta$-D-ribo-hexofuranosyl]adenine (15). Compound 15 (132 mg, 45\%) was prepared from 14 (247 $\mathrm{mg}, 0.42 \mathrm{mmol}$ ) by a similar procedure as that described for the synthesis of 7. ${ }^{1} \mathrm{H} \mathrm{NMR}\left(\mathrm{CDCl}_{3}\right): \delta 9.31(\mathrm{~s}, 1 \mathrm{H}), 8.77(\mathrm{~s}$, $1 \mathrm{H}), 8.11-7.12(\mathrm{~m}, 20 \mathrm{H}), 6.14(\mathrm{~s}, 1 \mathrm{H}), 5.52(\mathrm{~d}, J=6.6 \mathrm{~Hz}$, $1 \mathrm{H}), 4.70(\mathrm{~s}, 1 \mathrm{H}), 4.48(\mathrm{~m}, 1 \mathrm{H}), 2.40(\mathrm{~m}, 4 \mathrm{H}), 1.18(\mathrm{~s}, 3 \mathrm{H}) . \mathrm{MS}$ (ES): $m / e 720.3(\mathrm{M}+\mathrm{H})$.

Cyclic tert-Butyl SATE Phosphoester of 9-[5',6'-Dideoxy-6'-(hydroxylphosphinyl)-2'- $C$-methyl- $\beta$-D-ribo-hexofuranosyl]adenine (18). A solution of $5(20 \mathrm{mg}, 0.056 \mathrm{mmol})$ and tributylamine $(50 \mu \mathrm{L}, 0.20 \mathrm{mmol})$ in $\mathrm{H}_{2} \mathrm{O}(0.5 \mathrm{~mL})$ was evaporated under reduced pressure. The residue was repeatedly coevaporated with anhydrous ethanol and toluene. To the resulting oil were added pyridine $(3 \mathrm{~mL})$, thioester 16 (100 $\mathrm{mg}, 0.61 \mathrm{mmol}$ ), and 1-mesitylene-2-sulfonyl-3-nitro-1,2,4triazole $(83 \mathrm{mg}, 0.28 \mathrm{mmol})$. The reaction mixture was stirred at room temperature for $18 \mathrm{~h}$ and quenched by the addition of tetrabutylammonium bicarbonate buffer $(2 \mathrm{~mL}, 1 \mathrm{M}$ solution, $\mathrm{pH}$ 8.0). The mixture was extracted with $\mathrm{CHCl}_{3}(3 \times 10 \mathrm{~mL})$. The organic solution was washed with brine $(10 \mathrm{~mL})$, dried with $\mathrm{Na}_{2} \mathrm{SO}_{4}$, and concentrated to dryness. Silica gel chromatography $\left(\mathrm{CH}_{2} \mathrm{Cl}_{2}: \mathrm{MeOH}=95: 5\right)$ yielded $13 \mathrm{mg}(48 \%)$ of 18. ${ }^{1} \mathrm{H}$ NMR $\left(\mathrm{CD}_{3} \mathrm{OD}\right): \delta 8.26(\mathrm{~s}, 1 \mathrm{H}), 8.24(\mathrm{~s}, 1 \mathrm{H}), 6.04(\mathrm{~s}, 1 \mathrm{H})$, $4.18(\mathrm{~m}, 4 \mathrm{H}), 3.26(\mathrm{t}, J=6.3 \mathrm{~Hz}, 2 \mathrm{H}), 2.51-1.95(\mathrm{~m}, 4 \mathrm{H}), 1.22$ (s, 9H), $1.08(\mathrm{~s}, 3 \mathrm{H})$. MS (ES): m/e $486.3(\mathrm{M}+\mathrm{H})$.

9-[3'-O-tert-Butyldimethylsilyl-5',6'-dideoxy-6'-(hydroxyphosphinyl)-2'-C-methyl- $\beta$-D-ribo-hexofuranosyl]adenine (19). To a solution of $16(114 \mathrm{mg}, 0.18 \mathrm{mmol})$ and imidazole ( $55 \mathrm{mg}, 0.8 \mathrm{mmol})$ in DMF $(3 \mathrm{~mL})$ was added tertbutyldimethylsilyl chloride $(62 \mathrm{mg}, 0.41 \mathrm{mmol})$. The reaction mixture was stirred at $45^{\circ} \mathrm{C}$ for $24 \mathrm{~h}$ and quenched by addition of methanol $(1 \mathrm{~mL})$. The mixture was evaporated under reduced pressure and diluted with $\mathrm{CH}_{2} \mathrm{Cl}_{2}(50 \mathrm{~mL})$. The solution was washed with aqueous $\mathrm{NaHCO}_{3}$ solution $(30 \mathrm{~mL})$ and brine $(30 \mathrm{~mL})$. It was dried with $\mathrm{Na}_{2} \mathrm{SO}_{4}$ and concentrated to dryness to give $N^{6}$-benzoyl-9-[5', $6^{\prime}$-dideoxy- $6^{\prime}$-(dibenzyloxyphosphinyl)-2'-C-methyl-3'-O-tert-butyldimethylsilyl- $\beta$-D-ribohexofuranosyl]adenine. The crude nucleoside was subjected to a similar procedure as that described for the synthesis of 2 to give $70 \mathrm{mg}$ (95\% from 16) of 19. ${ }^{1} \mathrm{H}$ NMR $\left(\mathrm{CD}_{3} \mathrm{OD}\right): \delta 8.24(\mathrm{~s}$, $1 \mathrm{H}), 8.21(\mathrm{~s}, 1 \mathrm{H}), 6.02(\mathrm{~s}, 1 \mathrm{H}), 4.25(\mathrm{~d}, J=7.5 \mathrm{~Hz}, 1 \mathrm{H}), 4.02$ $(\mathrm{m}, 1 \mathrm{H}), 2.05(\mathrm{~m}, 4 \mathrm{H}), 0.99(\mathrm{~s}, 9 \mathrm{H}), 0.98(\mathrm{~s}, 3 \mathrm{H}), 0.25(\mathrm{~s}, 3 \mathrm{H})$. MS (ES): $m / e 474.3(\mathrm{M}+\mathrm{H})$.

HCV Replicon Assay and Cytotoxicity Studies. A previously reported HCV subgenomic replicon system was used to test the antiviral effect of adenosine phosphonate analogues $\mathbf{1 - 5}$ and a bis-SATE prodrug $\mathbf{5 b}$ in Huh7 cells. Conditions for the assay were similar to those previously described..$^{25}$ Briefly, replicon cells were seeded in a 96 -well plate at 6000 cells per well. Compounds were added immediately after seeding. After 48-h incubation, cells were lysed, and luciferase activity in cell lysate was measured. Reduction of HCV replicon RNA was calculated on the basis of the reduction of luciferase activity and expressed as $\mathrm{EC}_{50}$ (concentration to reduce $50 \%$ of viral replication). The cytotoxicity of a compound in Huh7 cell was determined by a colorimetric assay using 3-(4,5-dimethylthiazol-2-yl)-2,5-diphenyltetrazolium bromide (MTT) reagent. The results were expressed as $\mathrm{CC}_{50}$ (concentration to reduce $50 \%$ of cell viability).

Nucleoside Phosphono Diphosphate Incorporation Assays. HCV NS5B with a C-terminal His-tag and 21 amino acid truncation was expressed and purified as reported. ${ }^{31}{ }^{33} \mathrm{P}$ Labeled pGpC primer was prepared by incubating $\mathrm{GpC}$ dinucleotide (Sigma) with $\left[\gamma_{-}{ }^{33} \mathrm{P}\right] \mathrm{ATP}(3000 \mathrm{Ci} / \mathrm{mmol}$, PerkinElmer) and T4 polynucleotide kinase (Ambion) as described. ${ }^{25}$ A typical nucleotide incorporation assay was carried out at 30 ${ }^{\circ} \mathrm{C}$ in $10 \mu \mathrm{L}$ of $50 \mathrm{mM}$ HEPES (pH 7.3), $10 \mathrm{mM}$ DTT, $5 \mathrm{mM}$ $\mathrm{MgCl}_{2}, 20 \mu \mathrm{M}$ RNA template, $20 \mu \mathrm{M}$ of $\left[5^{\prime}-{ }^{33} \mathrm{P}\right] \mathrm{GpC}$, and various concentrations of an elongation nucleotide. For the initial evaluation of nucleotide incorporation by NS5B RdRp, the reaction was incubated for $1 \mathrm{~h}$ with $2.5 \mu \mathrm{M}$ NS5B RdRp and $1 \mathrm{mM}$ compound or control ATP. For steady-state kinetic analysis, a reaction was incubated for 15 min with $1 \mu \mathrm{M}$ NS5B RdRp. The assay was quenched by addition of $1 \mu \mathrm{L}$ of $0.5 \mathrm{M}$ EDTA. Subsequently, the reaction mixture was treated with $10 \mu \mathrm{L}$ of loading buffer (90\% formamide, $0.025 \%$ bromophenol blue, and $0.025 \%$ xylene cyanol) and heated to $70{ }^{\circ} \mathrm{C}$ for $2-5$ min prior to loading $2 \mu \mathrm{L}$ onto a denaturing $25 \%$ polyacrylamide-7 M urea-TBE gel. Electrophoresis was performed in $1 \times$ TBE at $70-90 \mathrm{~W}$. Gels were visualized and analyzed using a Phosphor Imager.

For steady-state kinetic analysis, apparent Michaelis constant $\left(K_{m}\right)$ and the maximal velocity $\left(V_{\max }\right)$ for a phosphono diphosphate substrate was determined at the fixed concentration of template/primer $(20 \mu \mathrm{M})$. The substrate concentration was varied from $K_{m} / 2$ to $10 K_{m}$. Initial velocity at each substrate concentration was determined, and the data were fitted into a Michaelis-Menten equation for calculation of $K_{m}$ and $V_{\max }$ using KaleidaGraph. The inhibitory experiments for a nucleoside phosphono diphosphate against ATP incorporation were performed under the standard assay conditions as described above. ATP concentration was fixed at $1 \mathrm{mM}$. Initial velocity at various concentrations of inhibitor was determined, and the inhibition constant $K_{i}$ was calculated by plotting $1 / v_{\mathrm{i}}$ vs inhibitor concentration using a Dixon plot.

Acknowledgment. We would like to acknowledge Dr. Vicky Lai, who performed the HCV replicon assays; Dr. Stephanie Shaw, for assisting with the manuscript preparation; and Dr. Teresa Cain, for helping with the purification of the phosphonates described in this paper.

\section{References}

(1) Choo, Q. L.; Kuo, G.; Weiner, A. J.; Overby, L. R.; Bradley, D. W.; M., H. Isolation of a cDNA clone derived from a blood-borne non-A, non-B viral hepatitis genome. Science 1989, 244, 359362. 
(2) World Health Organization Hepatitis C. Seroprevalence of hepatitis $\mathrm{C}$ virus $(\mathrm{HCV})$ in a population sample. Week. Epidemiol. Rec. 1996, 71, 346-349.

(3) Manns, M. P.; McHutchison, J. G.; Gordon, S. C.; Rustgi, V. K.; Shiffman, M.; Reindollar, R.; Goodman, Z. D.; Koury, K.; Ling, M.; Albrecht, J. K. Peginterferon alfa-2b plus ribavirin compared with interferon alfa-2b plus ribavirin for initial treatment of chronic hepatitis C: A randomised trial. Lancet 2001, 358, 958965.

(4) Wu, J. Z; Hong, Z. Targeting NS5B RNA-dependent RNA polymerase for anti-HCV chemotherapy. Curr. Drug Targets Infect. Disord. 2003, 3, 207-219.

(5) Holy, A. Phosphonomethoxyalkyl analogues of nucleotides. Curr. Pharm. Des, 2003, 9, 2567-2592.

(6) Johansson, N. G.; Eriksson, S. Structure-activity relationships for phosphorylation of nucleoside analogues to monophosphates by nucleoside kinases. Acta Biochim. Pol. 1996, 43, 143-160.

(7) De Clercq, E.; Holy, A.; Rosenberg, I.; Sakuma, T.; Balzarini, J.; Maudgal, P. C. A novel selective broad-spectrum anti-DNA virus agent. Nature 1986, 323, 464-467.

(8) Balzarini, J.; Naesens, L.; Herdewijn, P.; Rosenberg, I.; Holy, A.; Pauwels, R.; Baba, M.; Johns, D. G.; De Clercq, E. Marked in vivo antiretrovirus activity of 9-(2-phosphonylmethoxyethyl)adenine, a selective anti-human immunodeficiency virus agent. Proc. Natl. Acad. Sci. U.S.A. 1989, 86, 332-336.

(9) Balzarini, J.; Holy, A.; Jindrich, J.; Naesens, L.; Snoeck, R.; Schols, D.; De Clercq, E. Differential antiherpesvirus and antiretrovirus effects of the $(\mathrm{S})$ and $(\mathrm{R})$ enantiomers of acyclic nucleoside phosphonates: Potent and selective in vitro and in vivo antiretrovirus activities of (R)-9-(2-phosphonomethoxypropyl)-2,6-diaminopurine. Antimicrob. Agents Chemother. 1993, $37,332-338$.

(10) Suo, Z.; Johnson, K. A. Selective Inhibition of HIV-1 Reverse transcriptase by an antiviral inhibitor, $(R)$-9-(2-phosphonylmethoxypropyl)adenine. J. Biol. Chem. 1998, 273, 27250-27258.

(11) Raju, N.; Smee, D. F.; Robins, R. K.; Vaghefi, M. M. Synthesis and biological properties of purine and pyrimidine 5'-deoxy-5'(dihydroxyphosphinyl)-beta-D-ribofuranosyl analogues of AMP, GMP, IMP, and CMP. J. Med. Chem. 1989, 32, 1307-1313.

(12) Secrist, J. A., 3rd; Riggs, R. M.; Comber, R. N.; Montgomery, J. A. Synthesis of phosphonate analogues of dideoxyadenosine (DDA)-, dideoxycytidine (DDC)-, dideoxyinosine (DDI)-, and deoxythymidine (DDT)-5'-monophosphates. Nucleosides, Nucleotides 1992, 11, 947-956.

(13) Montgomery, J. A.; Thomas, H. J.; Kisliuk, R. L.; Gaumont, Y. Phosphonate analogue of 2'-deoxy-5-fluorouridylic acid. J. Med. Chem. 1979, 22, 109-111.

(14) Kim, C. U.; Luh, B. Y.; Martin, J. C. Regiospecific and highly stereoselective electrophilic addition to furanoid glycals: Synthesis of phosphonate nucleotide analogs with potent activity against HIV. J. Org. Chem. 1991, 56, 2642-2647.

(15) Khandazhinskaya, A. L.; Shirokova, E. A.; Skoblov, Y. S. Victorova, L. S.; Goryunova, L. Y.; Beabealashvilli, R. S. Pronyaeva, T. R.; Fedyuk, N. V.; Zolin, V. V.; Pokrovsky, A. G.; Kukhanova, M. K. Carbocyclic dinucleoside polyphosphonates: Interaction with HIV reverse transcriptase and antiviral activity. J. Med. Chem. 2002, 45, 1284-1291.

(16) Carroll, S. S.; Tomassini, J. E.; Bosserman, M.; Getty, K.; Stahlhut, M. W.; Eldrup, A. B.; Bhat, B.; Hall, D.; Simcoe, A L.; LaFemina, R.; Rutkowski, C. A.; Wolanski, B.; Yang, Z.; Migliaccio, G.; De Francesco, R.; Kuo, L. C.; MacCoss, M.; Olsen, D. B. Inhibition of hepatitis $\mathrm{C}$ virus RNA replication by $2^{\prime}-$ modified nucleoside analogs. J. Biol. Chem. 2003, 278, 1197911984.
(17) Périgaud, C.; Gosselin, G.; Lefebvre, I.; Girardet, J. L.; Benzaria S.; Barber, I.; Imbach, J. L. Rational design for cytosolic delivery of nucleoside monphosphates: "SATE" and "DTE" as enzymelabile transient phosphate protecting groups. Bioorg. Med. Chem. Lett. 1993, 3, 2521-2526.

(18) Jones, G. H.; Moffatt, J. G. The synthesis of 6'-deoxyhomonucleoside 6'-phosphonic acids. J. Am. Chem. Soc. 1968, 90, 53375338.

(19) Hollmann, J.; Schlimme, E. Darstellung und Konformationszuordnung einiger 5'-homologer adenosinderivate. Liebigs Ann. Chem. 1984, 98-107.

(20) Jones, G. H.; Hamamura, E. K.; Moffatt, J. G. Stable Wittig reagent suitable for the synthesis of $\alpha, \beta$-unsaturated phosphonates. Tetrahedron Lett. 1968, 55, 5731-5734.

(21) Merlo, V.; Reece, F. J.; Roberts, S. M.; Gregson, M.; Storer, R. Synthesis of optically active 5'-noraristeromycin: Enzymecatalysed kinetic resolution of 9-(4-hydroxycyclopent-2-enyl)purines. J. Chem. Soc. Perkin Trans. 1 1993, 15, 1717-1718.

(22) Dyatkina, N. B.; Theil, F.; Janta-Lipinski, M. Stereocontrolled synthesis of the four stereoisomeric diphosphorylphosphonates of carbocyclic 2',3'-dideoxy-2',3'-didehydro-5'-noradenosine. Tetrahedron 1995, 51, 761-772.

(23) Dyatkina, N.; Semizarov, D.; Victorova, L.; Krayevsky, A.; Theil, F.; Janta-Lipinski, M. Synthesis of four stereisomers of carbocyclic 5'-NOR D4A and evaluation of their triphosphates as substrates for DNA polymerases. Nucleosides, Nucleotides $\mathbf{1 9 9 5}$, $14,723-726$.

(24) Harry-O'Kuru, R. E.; Smith, J. M.; Wolfe, M. S. A short, flexible route toward 2'-branched ribonucleosides. J. Org. Chem. 1997 $62,1754-1759$.

(25) Shim, J.; Larson, G.; Lai, V.; Naim, S.; Wu, J. Z. Canonical 3'deoxyribonucleotides as a chain terminator for HCV NS5B RNAdependent RNA polymerase. Antivir. Res. 2003, 58, 243-251.

(26) Shim, J. H.; Larson, G.; Wu, J. Z; Hong, Z. Selection of 3'-template bases and initiating nucleotides by hepatitis $\mathrm{C}$ virus NS5B RNA-dependent RNA polymerase. J. Virol. 2002, 76 7030-7039.

(27) Ohno, Y.; Spriggs, D.; Matsukage, A.; Ohno, T.; Kufe, D. Sequence-specific inhibition of DNA strand elongation by incorporation of 9-beta-D-arabinofuranosyladenine. Cancer Res. 1989, 49, 2077-2081.

(28) Ohno, Y.; Spriggs, D.; Matsukage, A.; Ohno, T.; Kufe, D. Effects of 1-beta-D-arabinofuranosylcytosine incorporation on elongation of specific DNA sequences by DNA polymerase beta. Cancer Res. 1988, 48, 1494-1498.

(29) Freeman, G. A.; Rideout, J. L.; Miller, W. H.; Reardon, J. E. 3'Azido-3', 5'-dideoxythymidine-5'-methylphosphonic acid diphosphate: Synthesis and HIV-1 reverse transcriptase inhibition. J. Med. Chem. 1992, 35, 3192-3196.

(30) Benzaria, S.; Maury, G.; Gosselin, G.; Rittinger, K.; Divita, G.; Goody, R. S.; Imbach, J.-L. Synthesis of 2',3',5'-trideoxyuridine5 '-methylphosphonic acid and its diphosphate derivative. Study of the interaction with HIV-1 reverse transcriptase. Antivir. Chem. Chemother. 1994, 5, 221-228.

(31) Zhong, W.; Ferrari, E.; Lesburg, C. A.; Maag, D.; Ghosh, S. K.; Cameron, C. E.; Lau, J. Y.; Hong, Z. Template/primer requirements and single nucleotide incorporation by hepatitis $\mathrm{C}$ virus nonstructural protein 5B polymerase. J. Virol. 2000, 74, 9134-9143

JM049029U 